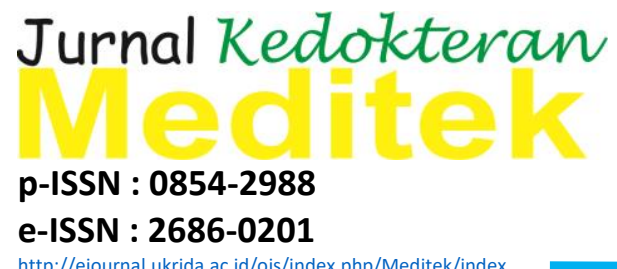

\title{
Profil Penderita HIV / AIDS di RSUD Koja
}

\author{
Cliff Clarence Haliman ${ }^{1}$, Suzanna Ndraha ${ }^{1}$ \\ ${ }^{1}$ Departemen Ilmu Penyakit Dalam Fakultas Kedokteran Universitas Kristen Krida Wacana \\ Alamat Korespondensi: cliff_md@ymail.com
}

\begin{abstract}
Abstrak
Human Immunodeficiency Virus (HIV) menurunkan kualitas hidup penderitasesuai dengan perkembangan penyakit dan munculnya manifestasi klinisAcquired Immune Deficiency Syndrome (AIDS).Perlu diketahui profil penderita untuk menyediakan pengangan yang sesuai.Penelitiandeskriptif potong lintang inidilakukan di ruangan rawat inap Bagian Ilmu Penyakit Dalam RSUD Koja pada periode 26 Juni 2017 sampai dengan 9 Agustus 2017. Populasi sampel adalah semua pasien HIV/AIDS di Bagian Ilmu Penyakit Dalam RSUD Koja Jakarta. Dari 19 orang pasien dengan HIV/AIDS yang dirawat, didapatkan prevalensi penderita laki-laki sebanyak 57,9\% dan perempuan sebanyak $42,1 \%$. Prevalensi pada kelompok usia 20-29 tahun sebesar 10,5\%, kelompok usia 30-39 tahun 57,9\%, kelompok usia 40-49 tahun 26,3\% dan kelompok usia 50-59 tahun 5,3\%. Status gizi pada penderita HIV/AIDS didapatkan berat badan kurang $73,7 \%$, berat badan normal $21,1 \%$, dan berisiko obesitas 5,2\%. Ditemukan 68,4\% menderita kelainan pada mulut dan 36,8\% menderita kelainan pada kulit.. Prevalensi faktor risiko pada pasien yang diteliti sebagai berikut: pengguna narkotika, psikotropika dan zat adiktif lainnya (NAPZA) suntik sebanyak 36,8\%, pasangan seks multipel 26,3\%, risiko penularan heteroseksual $21,1 \%$ dan faktor risiko yang tidak diketahui sebanyak 21,1\%.Simpulan:profil pasien HIV/ AIDS di RSUD Koja paling banyak ditemukan pada jenis kelamin laki-laki dan dalam rentang usia 30-39 tahun. Manifestasi klinis yang paling sering ditemukan pada pasien tersebut merupakan kelaninan mulut yang ditandai dengan kandidosis oral. Faktor risiko yang paling banyak ditemui pada subjek adalah penggunaan NAPZAsuntik.
\end{abstract}

Kata kunci: HIV-AIDS, infeksi oportunistik, profil karakteristik

\section{HIV-AIDS Patients Profile In Koja Regional Hospital}

\begin{abstract}
Human Immunodeficiency Virus (HIV)causes deterioration of the patient's quality of life, in accordance with the progression of Acquired Immune Deficiency Syndrome (AIDS).The profile of patients needs to be identified in order to provide appropriate management. This descriptive crosssectional study describes the profiles of HIV infected patients admitted in internal medicine in-patient section of Koja district hospital between June and August 2017. Nineteen patients were admitted during this period, which comprised of $57.9 \%$ men and $42.1 \%$ women. Of the studied subjects, $10.5 \%$ were in the 20-29 years age group, 57,9\% were inthe 30-39 age group, $26.3 \%$ were in the 40-49 age group, and $5.3 \%$ were in the 50-59 age group. In terms of nutritional status, $73.7 \%$ ad low bodyweight, $21.1 \%$ had normal bodyweight and $5.3 \%$ wereat risk of obesity. Most patients had oral clinical manifestations(68.4\%) and skinlesions (36.8\%). In terms of risk factors, 36.8\% of the studied patients were intravenous drug users, 26.3\%hadmultiple sex partners, $21.1 \%$ were at risk of heterosexual transmission and 21.1\%had unknown risk factors. This study concludes that male and patients in the age group of 30-39 constituted the largest prevalence of cases. The most common clinical manifestation was oral candidiasis. The most common risk factor in HIV patients was the use of intravenousdrug use.
\end{abstract}

Keywords: characteristic profile,HIV-AIDS, opportunistic infection 


\section{Pendahuluan}

Acquired Immune Deficiency Syndrome (AIDS) merupakan sindroma penyakit yang disebabkan oleh Human Immunodeficiency Virus (HIV). Virus tersebutmerusak sistem kekebalan tubuh manusia dan mengakibatkan turun atau hilangnya daya tahan tubuh, sehingga mudah terjadi penyakit infeksi. Human immunodeficiency virus dianggap sebagai agen penyebab AIDS. ${ }^{1}$

Kasus pertama HIV/AIDS di Indonesia ditemukan pada tahun 1987 di Bali dan terus meningkat sejak tahun 1995. ${ }^{1,2}$ Pusat Pengendalian dan Pencegahan Penyakit memperkirakan 49.000 kasus HIV baru per tahun pada tahun 2008-2010. ${ }^{2}$ Infeksi virus ini bahkan telah menyebabkan kematian lebih dari 25 juta orang di seluruh dunia, dan sebanyak 20 sampai40 juta orang di seluruh dunia hidup dengan HIV/AIDS. ${ }^{2}$ HIVmenurunkan kualitas hidup penderita sesuai dengan perkembangan penyakit dan munculnya manifestasi klinis. ${ }^{3}$

Pada sejarah epidemik dari HIV, penderita HIV positif yang memiliki jumlah sel CD4 cukup tinggi cenderung tidak memiliki gejala, sehingga diklasifikasikan sebagai HIVasimptomatis. ${ }^{4}$ Infeksi HIV akan berlanjut menjadi AIDS. Penyebab morbiditas dan mortalitas yang terbesar pada penderita AIDS adalah infeksi oportunistik, dimana menurunya daya tahan tubuh yang ditandai dengan jumlah sel CD4 yang rendah. ${ }^{5}$ Pada pemeriksaan kasus HIV, leukosit terlihat umumnya normal, akan tetapi, jika ditemukan leukopenia pada orang dengan HIV/AIDS, biasanya dikarenakan infeksi yang disebabkan oleh bakteri, virus, maupun keadaan stres psikologis. ${ }^{1}$ Pada pasien dengan HIV, eritrosit, hemoglobin, dan hematokrit umumnya rendah terutama pada pria dibandingkan pada wanita. Anemia adalah kelainan yang paling sering dijumpai pada penderita HIV/AIDS, hal ini bisa disebabkan karena berkurangnya produksi eritrosit karena adanya faktor yang menekan Colony Forming Unit: Granulocyte, Erythrocyte, Macrophage, Megakaryocyte (CFU-GEMM) misalnya sitokin inflamasi atau HIV. Profil CD4 dan Total Lymphocyte Count(TLC) sendiri umumnya lebih rendah pada pria dibandingkan pada wanita. ${ }^{1}$

Pada tahun 1981 untuk pertama dilaporkan terdapat epidemic pada laki-laki yang memiliki oreintasi homoseksual. Dilaporkan terdapat 5 kasus Pneumocystis carinii pneumonia pada laki-laki usia muda yang sehat. ${ }^{6,7}$.Di Indonesia sebagian kasus berkombinasi dengan sariawan oral pada lakilaki homoseksual yang sehat sebelumnya, serta infeksi herpes perianal ulserasi kronik. ${ }^{3}$

Tujuan umum dari penelitian ini adalah untuk mengetahui profil penderita HIV/AIDS di RSUD Koja. Adapun tujuan khusus dari penelitian ini adalah untuk mengetahui sebaran karakteristik pasien HIV/AIDS di RSUD Koja menurut umur, jenis kelamin, infeksi oportunistik, profil pemeriksaan fisik, profil pemeriksaan laboratorium, dan faktor risiko.

\section{Metode}

Penelitian ini merupakan suatu penelitian deskriptif dengan metode potong lintang. Penelitian inidilakukan di ruangan rawat inap Bagian Ilmu Penyakit Dalam RSUD Koja pada periode 26 Juni 2017 sampai 9 Agustus 2017.Populasi sampel adalah semua pasien HIV/AIDS di Bagian Ilmu Penyakit Dalam RSUD Koja, Jakarta.

Kriteria inklusi dalam penelitian ini yaitu: 1) semua pasien yang telah didiagnosis HIV berdasarkan serologi 2) berusia 20-59 tahun 3) pasien yang dirawat inap. Kriteria eksklusi pada penelitian ini adalah: 1) pasien yang menolak ikut serta di dalam penelitian.Instrumen pengumpulan data berupa lembar data penelitian yang mencatat karakteristik subjek berupa usia, jenis kelamin, penggunaan napza suntik, heomoseksual, status gizi, kelainan mulut maupun kulit, dan hasil laboratorium.Analisis statistik dilakukan dengan menggunakan SPSS versi 16.0 untuk Windows. Analisis univariat dilakukan dengan melihat rata-rata dan karakteristik masingmasing variabel.

\section{Kaji Etik}

Penelitian ini telah mendapatkan keterangan lolos kaji etik dari Komite Etik Penelitian Kedokteran dan Kesehatan Rumah Sakit Umum Daerah Koja, Provinsi DKI Jakarta dengan nomor pengajuan 02-2017.

\section{Hasil}

Dari hasil pengumpulan data yang terlah dilakukan pada populasi pasien HIV/AIDS yang dirawat inap di Bagian Ilmu Penyakit Dalam di RSUD Koja dari Juni 2017 sampai 
dengan Agustus 2017, dan didapatkan 19 subjek. Karakteristik dapat dilihat pada Tabel 1.

Tabel 1. Profil Pasien HIV/AIDS di RSUD Koja dari Juni 2017 sampai dengan Agustus 2017

\begin{tabular}{lc}
\hline & $\begin{array}{c}\text { Persentase } \\
(\%)\end{array}$ \\
\hline Jenis Kelamin & 57,9 \\
Laki-laki & 42,1 \\
Perempuan & 10.5 \\
Usia & 57.9 \\
20-29 tahun & 26,3 \\
30-39 tahun & 5,3 \\
40-49 tahun & \\
50-59 tahun & 73.7 \\
Status Gizi & 21.1 \\
Berat badankurang & 5.3 \\
Berat badannormal & \\
Berat badan berisiko obesitas & 63.2 \\
Pemeriksaan Kulit & 36.8 \\
Tidak ada kelainan kulit & \\
Ada kelainan kulit & 31.6 \\
Pemeriksaan Mulut & 68.4 \\
Tidak ada kelainan mulut & \\
Ada kelainan mulut & 36.8 \\
Faktor Risiko & 26.3 \\
Pengguna NAPZASuntik & 21.1 \\
Pasangan Seks Multipel & 21.1 \\
Risiko penularan heteroseksual & \\
Tidak diketahui & \\
\hline
\end{tabular}

Sebagaimana terlihat pada Tabel 1 , dari 19 subjek didapatkan prevalensi pada laki-laki lebih tinggi daripada perempuan. Berdasarkan usia, angka paling banyak ditemukan pasien HIV/AIDS pada kelompok usia 30-39 tahun diikuti oleh usia 40-49 dan usia 20-29, sedangkan angka terendah ditemukan pasien HIV/AIDS pada kelompok usia 60-59 tahun. Rata-rata usia pasien HIV/AIDS adalah 36,9 \pm SD 8,2 tahun dengan usia terkecil 25 tahun serta usia terbesar 54 tahun.

Dari 19 subjek dapat dihitung distribusi profil pemeriksaan fisik pasien HIV/AIDS berdasarkan status gizi, pemeriksaan kulit, dan pemeriksaan mulut. Status gizi pasien HIV/AIDS yang dirawat di RSUD Koja kebanyakan dalah berat badan kurang. Ratarata Indeks Massa Tubuh (IMT) pada penelitian ini adalah $18,36 \pm \mathrm{SD} 1,60 \mathrm{~kg} / \mathrm{m}^{2}$ yaitu termasuk berat badan rendah dengan IMT terendah adalah $16,20 \mathrm{~kg} / \mathrm{m}^{2}$ dan IMT tertinggi adalah 23,00 $\mathrm{kg} / \mathrm{m}^{2}$. Pada pasien yang mengalami kelainan kulit, pada sebagian pasien dijumpai kulit kering atau papular pruritic eruption (PPE) sedangkan kelainan mulut yang terutama dijumpai berupa sariawan mulut atau tampak banyak keputihan atau kekuningan di lidah pasien.

Pada penelitian, semua 19 subjek yang diteliti menderita infeksi oportunistik. Satu subjek dapat mengalami satu atau lebih infeksi oportunistik. Berdasarkan Gambar 1, maka dapat dilihat bahwa dari 19 subjek, infeksi oportunistik yang paling sering ditemukan adalah kandidiasis oral sebesar $68,4 \%$ diikuti oleh tuberkulosis pulmonal sebesar $57,9 \%$ dan diare kronis sebesar 12,3\%.

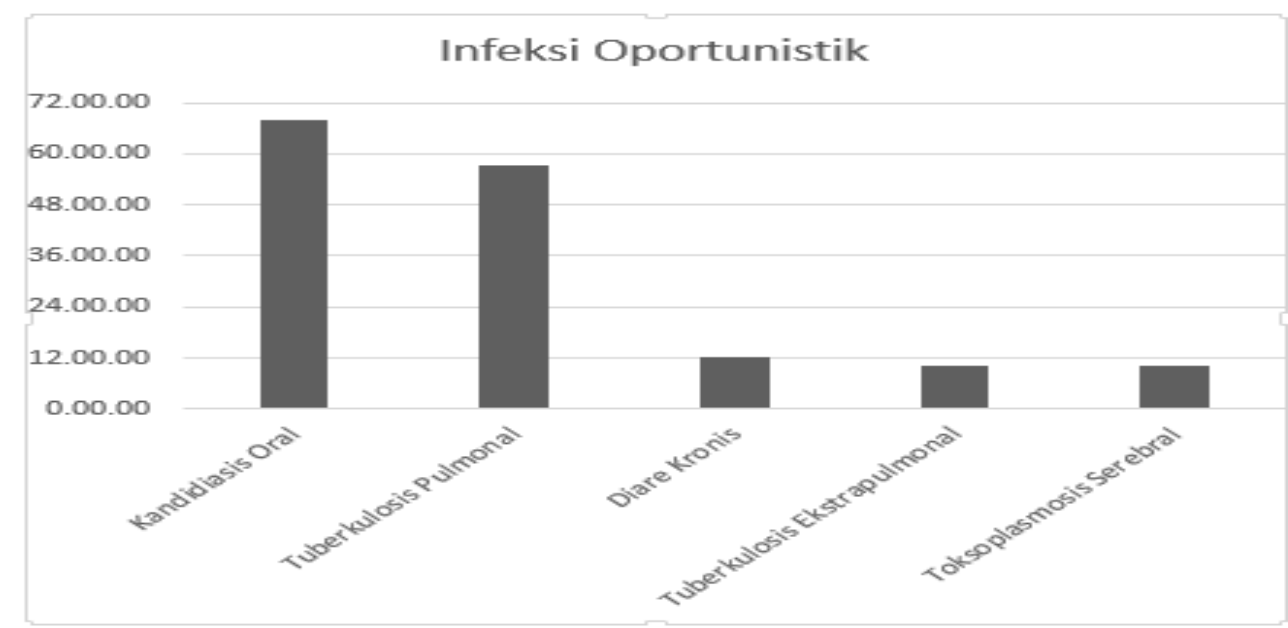

Gambar 1. Infeksi Oportunistik pada Pasien HIV/AIDS di RSUD Koja dari Juni 2017 sampai Agustus 2017 
Satu pasien bisa mempunyai satu atau lebih faktor risiko. Faktor risiko yang paling banyak ditemukan pada pasien HIV/AIDS pada penelitian ini adalah penggunaan NAPZA suntik diikuti oleh pasangan seks multipel.

Dari 19 subjek yang dilakukan penelitian, didapatkan hitungan distribusi profil pemeriksaan laboratorium pasien HIV/AIDS berdasarkan hitung jumlah limfosit (TLC), hemoglobin ( $\mathrm{Hb}$ ), hematokrit (Ht), hitung leukosit, hitung trombosit, kadar natrium dan kadar kalium. Ratarata hitung jumlah limfosit pasien HIV/AIDS adalah 22,0 \pm SD $12,5 \mathrm{sel} / \mathrm{mm}^{3}$ dengan hitung jumlah limfosit terendah adalah $10,2 \mathrm{sel} / \mathrm{mm}^{3}$ serta hitung jumlah limfosit tertinggi adalah 47,3 $\mathrm{sel} / \mathrm{mm}^{3}$. Rata-rata kadar hemoglobin pasien HIV/AIDS adalah 10,2 \pm SD 2,5 mg/dL dengan kadar hemoglobin terendah adalah 5,4 mg/dL dan hemoglobin tertinggi adalah 13,6 mg/dL. Ratarata kadar hematokrit adalah 29,8 \pm SD 6,7 \% dengan kadar hematokrit terendah adalah $15,5 \%$ dengan kadar hematokrit tertinggi adalah $38,9 \%$. Rata-rata kadar leukosit 6,82 \pm SD 5,08 x $10^{3} / \mu \mathrm{L}$ dengan kadar leukosit terendah adalah 1,04 x $10^{3} / \mu \mathrm{L}$ serta kadar leukosit tertinggi adalah 19,75 x $10^{3} / \mu \mathrm{L}$. Rata-rata kadar trombosit adalah 225,68 $\pm \mathrm{SD} 115,02 \times 10^{3} / \mu \mathrm{L}$ dengan kadar trombosit terendah adalah $12,00 \times 10^{3} / \mu \mathrm{L}$ serta kadar trombosit tertinggi adalah $452,00 \times 10^{3} / \mu \mathrm{L}$. Ratarata kadar natrium adalah $129,17 \pm \mathrm{SD} 8,46$ $\mathrm{mEq} / \mathrm{L}$ dengan kadar natrium terendah adalah $111,00 \mathrm{mEq} / \mathrm{L}$ dan kadar natrium tertinggi adalah $144,00 \mathrm{mEq} / \mathrm{L}$.

\section{Pembahasan}

Penelitian ini dilakukan secara potong lintang dengan mengambil subjek sebanyak 19 pasien dengan HIV/AIDS. Pada kelompok ini ditemukan lebih banyak pada pasien laki-laki.Hal ini sejalan dengan laporan kasus HIV/AIDS di Indonesia berdasarkan jenis kelamin sejak 1987 sampai dengan September 2014, yaitu lebih banyak terjadi pada kelompok laki-laki dengan persentase 58,07\%. ${ }^{2} \mathrm{Hal}$ ini disebabkan pada lakilaki lebih banyak yang menggunakan obat jarum suntik dan membeli seks tanpa menggunakan proteksi. ${ }^{2,8}$

Berdasarkan kelompok usia, pada penelitian ini paling banyak ditemukan pada kelompok usia 30-39 tahun diikuti oleh kelompok usia 40-49 tahun. Hasil penelitian ini tidak sesuai dengan penelitian bahwa kasus HIV/AIDS paling banyak terjadi pada kelompok usia produktif 20 29 tahun yaitu sebesar $37,9 \%$ sedangkan pada kelompok usia 30-39 tahun sebesar 28,5\%. ${ }^{2} \mathrm{Hal}$ ini disebabkan karena lebih tingginya pengetahuan tentang proteksi pada hubungan seks diluar nikah pada usia 15-24 tahun sesuai dengan laporan tahun $2016^{2,8}$

Infeksi oportunistik paling banyak ditemukan adalah kandidiasis oral yaitu sebesar $68,4 \%$ diikuti oleh diikuti oleh tuberkulosis pulmonal $(57,9 \%)$ dan diare kronis $(12,3 \%)$. Hasil penelitian ini sedikit berbeda dengan data dari penelitian yang dilakukan oleh Saldanha et al. yang menyatakan bahwa tuberkulosis pulmonal merupakan infeksi oportunistik tersering dengan persentase $45,3 \%$ pada pasien HIV. ${ }^{5}$ Tuberkulosis sendiri disebutkan merupakan penyebab utama kematian pada penderia HIV, terhitung sekitar satu dari tiga kematian terkait AIDS. ${ }^{9}$ Sedangkan, penelitian di India yang dilakukan oleh Chopra et al.ditemukan pasien HIV/AIDS dengan kandidiasis oral adalah sebesar 32,22\%. ${ }^{10}$ Akibat proses imunosupresi, pasien dengan HIV/AIDS rentan mendapat lesi kutan dan mukokutan yang multipel dan menyebar luas sedangkan pada individu yang immunokompeten, lesi tersebut biasanya terlokalisasi dan ditemukan satu lesi saja. ${ }^{11}$ Pasien HIV/AIDS dengan infeksi kandidiasis merupakan faktor eksogen yang penting untuk menilai keparahan dan cepatnya progresivitas infeksi HIV pada seorang individu. ${ }^{11}$ Pada penelitian di India yang dilakukan oleh Vyas et al. menemukan gejala diare kronis pada $38,66 \%$ pasien dengan HIV/AIDS. ${ }^{10}$ Terdapat banyak faktor yang dapat menyebabkan prevalensi infeksi parasit intestinal berbeda pada suatu populasi, diantaranya yang paling berpengaruh adalah faktor lingkungan dan faktor host. Beberapa penelitian dari pelbagai negara menemukan prevalensi parasitosis enterik pada pasien HIV berkisar $17-84 \% .{ }^{12-15} \mathrm{Hal}$ ini sangat berhubungan dengan lingkungan dan higienitas subjektif dari setiap individu. ${ }^{15-17}$

Status gizi pada pasien penelitian ini paling banyak ditemukan pasien HIV/AIDS yang kurang berat badan yaitu sebesar 73,7\%. Hasil penelitian ini sesuai dengan suatu studi oleh Sharma A et al di Amerika, yang menemukan indeks massa tubuh (IMT) pada pasien HIV kebanyakan pada 
kelompok berat badan rendah yaitu sebesar $36,5 \%$, sedangkan pada $30,9 \%$ pasien HIV ditemukan tergolong dalam kelompok berat badan normal. ${ }^{18}$ Salah satu faktor yang bertanggung jawab terhadap malnutrisi pada pasien dengan HIV adalah menurunnya nafsu makan yang disebabkan akibat kesulitan untuk makan karena infeksi dari oral thrush atau esofagitis yang disebabkan oleh Candida. Absorbsi yang buruk dari nutrisi biasanya disertai dengan diare yang disebabkan oleh infeksi dari Salmonella atau Mycobacterium avium, virus seperti Cytomegalovirus (CMV), parasit seperti Giardia. Selain itu, infeksi tersebut juga bisa menyebabkan rasa mual dan muntah. saluran gastrointestinal merupakan organ dengan jaringan limfoid terbesar di tubuh dan berhubungan langsung dengan infeksi HIV, yang menyebabkan kerusakan dari sel intestinal akibat dari mendatarnya villi dan menurunnya absorbsi D-xylose. Hal ini menyebabkan malabsorbsi dari karbohidrat dan lemak sehingga vitamin yang larut dalam lemak, dimana sangat berpengaruh terhadap sistem imum, tidak dapat diabsorbsi juga. ${ }^{19}$ Selain itu juga, nutrisi dibutuhkan lebih banyak pada kondisi badan dalam keadaan deman dan infeksi, sehingga penurunan berat badan akan semakin parah. ${ }^{19}$

Kelainan kulit yang ditemukan paling banyak pada penelitian ini berupa papular pruritic eruption (PPE) atau kulit yang terlalu kering. Hasil penelitian ini sesuai dengan penelitian di India yang menemukan prevalensi PPE pada pasien HIV hanya sekitar $7,77 \% .{ }^{10} \mathrm{PPE}$ merupakan dermatosis yang khusus karena sering dikaitkan dengan infeksi HIV lanjut yang tampak sebagai papul yang steril, nodul atau pustula dengan gambaran hiperpigmentasi dan urtikaria dengan pruritus. ${ }^{10}$

Penelitian ini menemukan $68,4 \%$ pasien HIV/AIDS mengalami kelainan mulut yang kebanyakan merupakan akibat dari infeksi jamur. Hasil penelitian ini sejalan dengan penelitian yang dilakukan oleh Egusa et al. (2008) yang menemukan kandidosis sebagai kelainan yang sering dijumpai pada mulut penderita HIV/AIDS. ${ }^{11}$ Candida $s p$ sendiri merupakan salah satu flora normal pada mulut manusia. Sistem imun yang berperan dalam mekanisme pertahanan pada flora normal tersebut adalah cellmediated imunity oleh $\mathrm{CD}^{+}{ }^{+} \mathrm{Th} 1(T$ Helper 1) yang jelas sangat menurun pada pasien HIV/AIDS sehingga menyebabkan infeksi oportunistik yang biasanya ditampilkan dengan oral thrush.Infeksi kandidiasis merupakan faktor eksogen yang penting untuk menilai keparahan dan cepatnya progresivitas infeksi HIV pada seorang individu. ${ }^{11}$

Pada pemeriksaan laboratorium ditemukan rata-rata hitung jumlah limfosit pada pasien HIV/AIDS di RSUD Koja sebesar 22,0 sel/ $/ \mathrm{mm}^{3}$ yaitu masih dalam batas normal. Hasil ini mungkin disebabkan karena pasien-pasien yang diteliti rata-rata sudah berobat dengan antiretroviral sehingga penurunan jumlah limfosit tidak terlalu buruk. Hasil penelitian ini berbeda dengan penelitian yang dilakukan Afiah Et al, dimana pada penelitian tersebut ditemukanpada pasien HIV/AIDS biasanya mengalami limfositopenia. ${ }^{1}$ Jumlah limfosit sendiridapat digunakan untuk memantau progresivitas HIV, yaitu penurunan yang cepat dari TLC dan $\mathrm{Hb}$ sehubungan dengan progresivitas HIV menjadi AIDS. ${ }^{20}$ Nilai rendah limfosit terjadi karena replikasi virus dalam sel merusak membran dan mengganggu fungsi sel sehingga mempengaruhi produksi limfosit. ${ }^{1}$

Rata-rata nilai hemoglobin pada pasien HIV/AIDS di RSUD Koja adalah sebesar 10,2 $\mathrm{mg} / \mathrm{dL}$ yaitu rendah sedangkan rata-rata nilai hematokrit adalah rendah yaitu $29,8 \%$. Hasil ini sesuai dengan beberapa penelitian Afiah et al yang menemukan nilai hematokrit dan hemoglobin yang rendah. ${ }^{1}$ Penilaian hemoglobin dan hematokrit penting untuk mengevaluasi anemia, karena anemia adalah kelainan yang paling sering dijumpai pada penderita HIV/AIDS. ${ }^{21}$. Hal ini bisa disebabkan karena berkurangnya produksi eritrosit karena adanya faktor yang menekan CFU-GEMM misalnya sitokin inflamasi atau HIV. ${ }^{1}$

Rata-rata nilai trombosit pada pasien HIV/AIDS di RSUD Koja dalam batas normal, yaitu $225,68 \times 10^{3} / \mu$ L.Hasil ini sesuai dengan penelitian oleh Afiah et $\mathrm{Al}$ yang menemukan bahwa umumnya trombosit normal pada pasien HIV/AIDS, ${ }^{1}$ namun bisa juga ditemukan trombositopenia akibat destruksi trombosit akibat antibodi yang prosesnya mirip dengan idiopatik trombositopenik purpura atau karena terhambatnya produksi platelet yang disebabkan 
terinfeksinya megakariosit pada sumsum tulang. ${ }^{22}$

Rata-rata nilai leukosit pada pasien HIV/AIDS di RSUD Koja dalam batas normal, yaitu $6,82 \times 10^{3} / \mu \mathrm{L}$. Hasil penelitian ini sesuai dengan penelitian yang dilakukan oleh Afiah Et Al yang menemukan nilai leukosit umumnya normal. Biasanya leukopenia pada penderita HIV disebabkan karena infeksi virus, bakteri, maupun stres psikologis. ${ }^{1}$

Untuk pemeriksaan elektrolit pada pasien HIV/AIDS yang dinilai pada penelitian ini adalah kadar natrium dan kadar kalium. Penelitian ini menemukan kadar natrium rata-rata rendah yaitu sebesar $129 \mathrm{mEq} / \mathrm{L}$. Hasil ini tidak sesuai dengan penelitian oleh Bagnis et $\mathrm{Al}$ yang menemukan rata-rata kadar natrium adalah normal yaitu 139 $\mathrm{mEq} / \mathrm{L} .{ }^{23}$ Namun beberapa penelitian terkini yang dilakukan oleh Xu et al menemukan sering terjadi hiponatremia pada pasien dengan HIV/AIDS yang dikaitkan dengan infeksi oportunistik (sekresi ADH yang abnormal pada pneumonia, pengurangan volume efektif pada diare kronis, insufisiensi adrenal, hipoaldosteronisme atau pemberian trimetroprim serta pentamidin pada pasien yang sakit berat). ${ }^{24}$ Penelitian tersebut menghubungkan bahwa hiponatremia berhubungan dengan tingkat keparahan dari HIV sendiri. ${ }^{24}$ Dengan terapi yang lebih baru, profil biokimiawi pada pasien HIV pada masa kini sudah kurang terjadi kelainan pada kadar elektrolit. ${ }^{23}$

Faktor risiko yang paling banyak ditemukan pada pasien HIV/AIDS pada penelitian ini adalah penggunaan NAPZA suntik yaitu sebesar $36,8 \%$ diikuti oleh pasangan seks multipel $26,3 \%$. Pada sebesar $21,1 \%$,faktor risiko tidak diketahui. Prevalensi pasien HIV/AIDS yang heteroseksual pada penelitian ini $21,1 \%$. Hasil ini sedikit berbeda dengan penelitian kasus AIDS di Indonesia paling banyak terjadi pada kelompok heteroseksual (57,9\%), diikuti pengguna narkoba injeksi sebesar $(24,8 \%)$, dan homoseksual $(4,9 \%) \cdot{ }^{25} \mathrm{Hal}$ ini sangat berhubungan dengan tingkat kejujuran dari pasien dimana di Indonesia sendiri, seks merupakan hal yang tabu. Hal ini juga ditandai beberapa subjek enggan memberikan informasi kemungkinan terkena HIV. ${ }^{2,8}$ Penggunaan zat narkoba dapat mempengaruhi penyebaran HIV melalui kebiasaan berbagi jarum suntik, dan seks bebas dibawah pengaruh narkoba, dan kemampuan untuk membuat keputusan yang wajar juga berkurang. ${ }^{26}$

\section{Simpulan}

Profil pasien HIV/ AIDS di RSUD Koja paling banyak ditemukan pada jenis kelamin lakilaki dan dalam rentang usia 30-39 tahun. Manifestasi klinis yang paling sering ditemukan pada pasien tersebut merupakan kelainan mulut yang ditandai dengan kandidosis oral, status gizi yang rendah, dan anemia. Fakto risiko yang paling banyak ditemui pada subjek adalah penggunaan napza suntik. Perlu dilakukan penelitian lebih lanjut untuk memahamiprofil penderita di masyarakat.

\section{Daftar Pustaka}

1. Afiah A, Arif M, Hardjoeno. Profil tes darah rutin dan jumlah limfosit total pada penderita HIV/AIDS. Indonesian Journal of Clinical Pathology And Medical Laboratory. 2007;13(2):56-9.

2. Kementerian Kesehatan RI. Infodatin: situasi dan analisis HIV/AIDS.Jakarta: Pusat Data dan Informasi Kementerian Kesehatan RI; 2014.

3. Sofitri, Ellyza N, Almurdi, Efrida. Diagnostic test on the fourth generation Human Immunodeficiency Virus in HIV suspects. Maret 2017.23(2):172-7.

4. Willard S, Holzemer WL, Wantland DJ, Cuca YP, Kirksey KM. Does "assymptomatic"mean without symptoms for those living with HIV infection? AIDS Care. 2009;21(3):322-8.

5. Saldanha D, Gupta N, Shenoy S, Saralaya V. Prevalence of oportunistic infections in AIDS patients in Mangalore, Karnataka. Tropical Doctor., 2008;38:172-3.

6. Piot P, Bartos M, Ghys PD, Walker N, Schwartlander B. The global impact of HIV/AIDS. Nature. 2001;410:968-73

7. Wolitski R,Valdiserri RO,Denning $\mathrm{PH}$, Levine WC. Are we headed for a resurgence of the HIV epidemic among men who have sex with men. AMJ Public Health.2001.91(6).883-8.

8. Kementerian Kesehatan RI. Kajian epidemiologi HIV Indonesia 2016.Jakarta: 
Direktorat Pencegahan dan Pengendalian Penyakit Kementerian Kesehatan RI, 2017.

9. Hoffmann C, Rockstroh K J. HIV 2015/16. Hamburg: Medizin Fokus Verlag. 2015.p.212.

10. Chopra S, Arora U. Skin, mucocutaneous manifestations: useful clinical predictors of HIV/AIDS. J Clin Diagn Res. 2012;6(10):1695-8.

11. Egusa H, Soysa NS, Arjuna N, Ellepola AN, Yatani H, Samaranayake LP. Oral candidosis in HIV-infected patients. Current HIV Research. 2008;6:485-99.

12. Sapkota D, Ghimire P, Manandhar S. Enteric parasitosis in patients with human immunodeficiency virus(HIV) infection and acquired immunodeficiency syndrome(AIDS) in Nepal. Journal of Nepal Health Research Council. 2004;2,1-5.

13. Berenji F, Sarvghad MR, Fata A, Hosseininejad Z, Saremi E, Ganjbaksh M, Jahanparvar RI. A study of prevalence of intestinal parasitic infection in HIV positive individuals in Marshhad, Northeast Iran. Jundishapur J Microbiol. 2010;3(2):615.

14. Udeh EO, Goselle ON, D-Papova DD, Abelau M, Popov TV, Jean N, et al. The prevalence of intestinal protozoans in HIV/AIDS patients in Abuja, Nigeria. Sci World J. 2008;3(3):1-4

15. Kurniawan A, Karyadi T, Dwintasari SW, Sari IP, Yunihastiti E, Djauzi S, et al. Intestinal parasitic infections in HIV/AIDS patients presenting with diarrhoea in Jakarta, Indonesia. Trans Royal Soc Tropical Med Hyg. 2009;103:892-8.

16. Vyas N, Sood S, Sharma B, Kumar M. The Prevalence of intestinal parasitic infestation and the related profile of the CD4+ counts in HIV/AIDS people with diarrhoea in Jaipur City. J Clin Diagn Res. 2013;7(3):454-6.

17. Berenji F, Sarvghad MR, Fata A, Hosseininejad Z, Saremi E, Ganjbaksh M, Jahanparvar RI.A study of prevalence of intestinal parasitic infection in HIV positive individuals in Marshhad, Northeast Iran. Jundishapur J Microbiol. 2010;3(2):61-5.

18. Sharma A, Hoover DR, Shi Q, Gustafson D, Michael W et al. Relationship between body mass index and mortality in HIV-infected HAART users in the Women's Interagency HIV Study.PloS ONE. 2015;10(12):1-16.

19. Duggal S, Chugh TD, Duggal AK.HIV and malnutrition: effects on immune system. Clinical and Developmental Immunology. 2012. Article ID 784740:1-8.

20. Lau B, Gange SJ, Phair JP, Riddler SA, Detels $\mathrm{R}$, Margolick JB. Use of total lymphocyte count andhemoglobin concentration for monitoring progression of HIV infection. PubMed. Aug15, 2005; 620-5

21. Sukartini N. Kelainan hematologi pada infeksi HIV dalam pendidikan berkesinambungan patologi klinik, Jakarta, Bagian PATKLIN-UI, 2002;106-15

22. Scaradavou thrombocytopenia. Blood Review. 2002;16:73-6.

23. Bagnis CI, Montcel STD, Fonfrede M, Jaudon MC, Thibault V. et al. Changing electrolyte and acid-base profile in HIV-infected patients in HAART Era. Nephron Physiol. 2006;103:131-8.

24. $\mathrm{Xu}$ L,Ye H, Huang F, Yang $\mathrm{Z}$, et al.Moderate/severe hyponatremia increase the risk of death among hospitalized Chinese human immunodeficiency virus/acquired immunodeficiency syndrome patients.PLoS One. 2014;9(10): e111077

25. Astindari, Lumintang H. Cara penularan HIV \& AIDS di unit perawatan intermediate penyakit infeksi RSUD Dr. Soetomo Surabaya. BIKKK. 2014:26(1).36-40

26. El-Bassela N, Shawa SA, Dasguptab A, Strathdeeb SA. Drug use as a driver of HIV risks: re-emerging and emerging issues. Curr Opin HIV AIDS. 2014;9(2):150-5. 